\title{
Experimental investigation on friction between foundation slabs and substructure
}

\author{
Klaus Holschemacher ${ }^{1}$, Philipp Löber ${ }^{2}$ \\ Structural Concrete Institute, HTWK Leipzig, Leipzig, Germany \\ E-mail: ${ }^{k}$ klaus.holschemacher@htwk-leipzig.de (corresponding author)
}

\begin{abstract}
For verification of structural safety (ultimate limit states - ULS) and serviceability (serviceability limit states - SLS) of reinforced concrete structures direct and indirect actions must be considered. The main reason for unexpected wide cracks in foundation slabs is restraint due to development and discharge of hydration heat, shrinkage and climatic actions. The amount of restraint is dependent on friction forces between the lower side of the foundation slab and the substructure. Friction coefficient is influenced by the properties of the sliding layer that is in many cases provided by two layers of PE foil.

In various normative regulations and design recommendations there are proposals for mean values of friction coefficients in the context of design of foundation slabs. Because these friction coefficients strongly differ even for comparable sliding layers an experimental investigation has been carried out aiming on better understanding of the friction behavior between foundation slabs and substructure. The paper describes the test program and reports the investigated friction coefficients.
\end{abstract}

Keywords: restraints, foundation slabs, slabs on ground, friction coefficient.

\section{Introduction}

\section{Construction details of foundation slabs}

There are different possible construction types (Figure 1), depending on the demands on foundation slabs. Those are resulting from structural exposures like frost-thaw-cycles, the desired use of the foundation slab (e.g. industrial floor, inside/outside, residential foundation slab, etc.) and the design principles ("no" cracks or limited cracks). The simplest form represents the slab resting on a subbase of frost protection gravel $(\mathrm{ca} .30 \mathrm{~cm})$. Depending on the acting forces and the quality of the subgrade (stiffness of the soil), an additional base layer may be required. Furthermore, it is required to have some sort of sliding or separation layer. If isolation is used, a steam barrier may be appropriate. The internal stresses caused by restraint due to temperature or shrinkage deformations are scaling based on the friction between concrete and base or subbase.

To reduce friction it is mandatory to include a sliding layer, which can be some sort of foil (Polyethylene - PE), maybe with lubricants, sand or bitumen. To enhance this friction reduction it is advisable to create a levelled and flat surface on the subbase, which can best be done with trowelled levelling concrete, although this effort is often not necessary.

\section{Design of foundation slabs}

For verification of structural safety (ultimate limit state - ULS) and serviceability (serviceability limit state - SLS) direct and indirect actions must be considered. The main reason for unexpected wide cracks in foundation slabs is restraint due to development and discharge of hydration heat, shrinkage and climatic actions. In principle, there are two design concepts for verification of restraints in foundation slabs. 

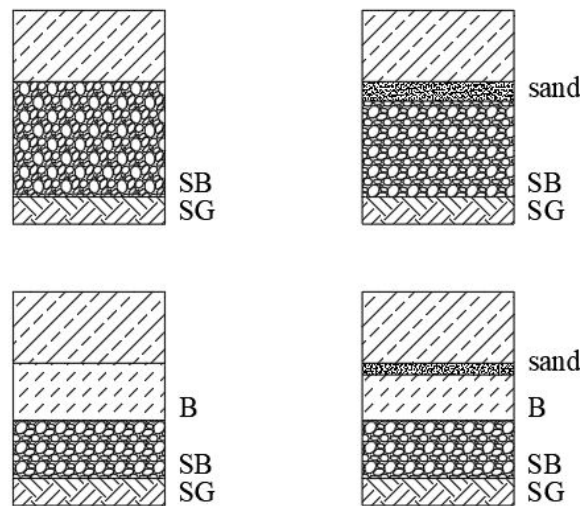
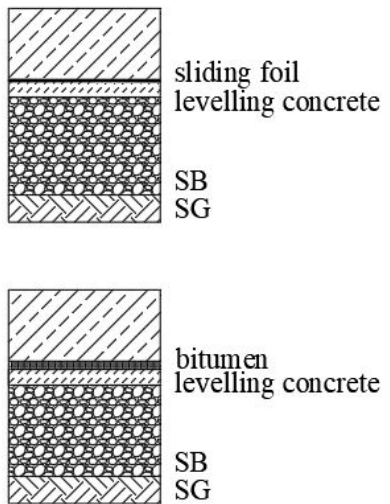

B base (hydraulically bounded base layer)

SB subbase (frost protection gravel)

SG subgrade (soil)

BB bituminous base

Figure 1. Ways of construction for different foundation slabs, according to (Schütte, 1997)

\section{Design concept 1}

Acceptation of cracks and assumption of a cracked section. Based on this assumption an arrangement of minimum reinforcement and crack width control is required. The decisive internal forces are to calculate for crack formation stage.

- Principle a: limitation of crack width with the aim of having many cracks with very little crack widths;

- Principle b: limitation of crack width with the aim of having little amount of cracks with larger crack widths.

Design concept 2

Avoidance of cracks and assumption of an uncracked section. In this case, the acting axial tensile force in the uncracked section is to calculate from the shear force limited by friction in the interface between the bottom of the foundation slab and the subbase. The acting tensile force must not exceed the resisting tensile force calculated with the axial tensile strength of concrete. Because of the uncertainty and scattering of concrete tensile strength, there is no absolute safety against cracking. Therefore, a minimum reinforcement is needed and to calculate for cracking forces.

Especially for foundations of with low dimensions and in watertight structures, design concept 2 is the preferred one. Therefore, the design rules will be explained more in detail for this concept.

If it is assumed that there is only a tensile restraint the resisting axial force $N_{\mathrm{r}}$ may be estimated according to Eq. (1):

$$
N_{\mathrm{r}}=A_{\mathrm{c}} \cdot f_{\mathrm{ct}},
$$

where: $A_{\mathrm{c}}$ - area of concrete cross section; $f_{\mathrm{ct}}$ - axial tensile strength of concrete

For $f_{\mathrm{ct}}$ the time dependence of concrete strength is to consider. If restraint is caused by hydration heat, the first cracking will occur few days after concreting. Therefore, a value lower than the tensile strength at concrete age of 28 days can be chosen for $f_{\text {ct. }}$ Otherwise, the concrete may have higher strength than was ordered. In many codes, minimum values for axial concrete strength are given to follow possible over strength.

Restraint caused by climatic influences may arise years after concreting of a foundation slab, e.g. when inspection or repair of a water tank is necessary. In this case, there is no water in the tank and during daylight the heating of concrete members caused by sun followed by a very rapid cooling down by rain or in the night will occur. When cracks will be formed in this situation it has to be taken into account that the axial concrete tensile strength may be higher than their 28 days value leading to higher axial cracking force $N_{\mathrm{r}}$.

The shear force $N_{\text {fr }}$ in the interface between the bottom of foundation slab and substructure or soil is to calculate according to Eq. (2)

$$
N_{\text {fr }}=\mu_{\text {eff }} \cdot \sigma_{0} \cdot b \cdot \frac{L}{2},
$$

where: $N_{\mathrm{fr}}-$ shear force in the interface; $\mu_{\mathrm{eff}}-$ effective friction coefficient; $\sigma_{0}$ - vertical pressure in the interface; $b-$ width of $1 \mathrm{~m} ; L$ - length of the foundation slab. 
The maximum friction coefficient decreases with increasing ground pressure $\sigma_{\mathrm{v}}$. In this case the resistance due to grain interlock is smaller compared to the shear resistance based on the inner friction angle $\varphi$ of the soil (Pettersson $\&$ Alemo, 2000; Röhling, 2009). Anyways, this is reduction only happens, when the sliding plane developes in a soil-like material (e.g. sand, gravel, soil). Thus, in case of thin slabs $(h<1.00 \mathrm{~m})$ the friction coefficient may be considerably higher than in thicker slabs.

For $N_{\mathrm{fr}} \leq N_{\mathrm{r}}$ there is high probability that the section remains uncracked. The minimum reinforcement $a_{\mathrm{s}, \min }$ is to calculate for $N_{\text {fr. }}$.

$$
a_{\mathrm{s}, \min }=\frac{N_{\mathrm{fr}}}{\sigma_{\mathrm{s}}}
$$

where: $a_{\mathrm{s}, \min }-$ minimum reinforcement due to restraint; $N_{\mathrm{fr}}-$ shear force in the interface; $\sigma_{\mathrm{s}}-$ steel stress

In Eq. (3) the steel stress $\sigma_{s}$ is to determine in accordance with the demands of crack width control. It is obvious that the friction coefficient $\mu_{\mathrm{eff}}$ is of essential importance for verification of uncracked stage and calculation of minimum reinforcement. A higher friction coefficient is resulting in an increasing demand on concrete strength or expense of reinforcement.

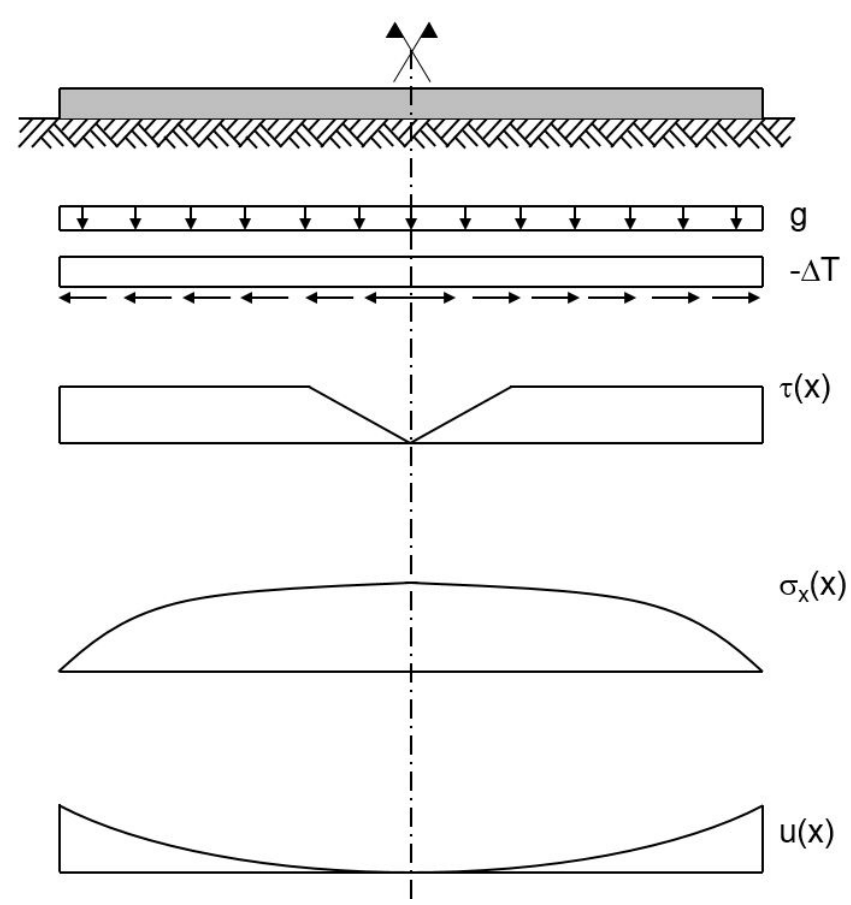

Figure 2. Stresses in a foundation slab caused by hindered deformations

Effects on the shear stresses in the interface (Figure 2):

- Vertical stresses, perpendicular to the interface area (slab thickness)

- Relative displacement $u$

- Roughness of the contact surfaces

- Properties of subbase

For realistic evaluations of friction coefficients, the DAfStb (German Committee for Reinforced Concrete) guideline "Waterproof concrete structures" (Deutscher Ausschuss für Stahlbeton Dezember, 2017) allows the performance of friction tests on slab sections. The friction coefficient represents the ratio between shear and normal force inside the joint.

$$
\mu=\frac{F_{\mathrm{R}}}{F_{\mathrm{N}}},
$$

where: $\mu$-friction coefficient; $F_{\mathrm{R}}$ - shear force in the joint; $F_{\mathrm{N}}$ - normal force in the joint (vertical force).

\section{Assumptions for the friction coefficient in literature}

The values for friction coefficients in literature are very scattered. On the one hand, there is no uniform testing procedure available On the other hand, the results greatly depend on the respective position of the sliding plane. This position may develop either in the sliding layer or in the levelling layer, if it is a soil-like material. If the sliding plane developes 
in a soil like material, there is a corellation of the friction coefficient and the vertical stresses in the sliding plane as it was mentioned above.

Table 1. Assumptions for friction coefficients from literature

\begin{tabular}{|c|c|c|c|c|c|}
\hline Subbase ${ }^{\text {a) }}$ & Reference & $\begin{array}{c}\text { Separation / sliding } \\
\text { layer }\end{array}$ & $\begin{array}{l}\text { Slab } \\
\text { thickness }\end{array}$ & $\begin{array}{l}\text { Friction } \\
\text { coefficient } \mu_{\mathrm{eff}} \\
\text { for first } \\
\text { displacement }\end{array}$ & $\begin{array}{l}\text { Friction } \\
\text { coefficient } \mu_{\mathrm{r}} \\
\text { for repeated } \\
\text { displacement }\end{array}$ \\
\hline \multirow[t]{5}{*}{$\begin{array}{l}\text { coarse without } \\
\text { sand layer (i.e. } \\
\text { gravel) }\end{array}$} & $\begin{array}{l}\text { (Deutscher Ausschuss für Stahlbe- } \\
\text { ton Entwurf, März 2011; Österrei- } \\
\text { chische Bautechnik Vereinigung, } \\
\text { 2018) }\end{array}$ & - & & $1.4 \ldots 2.1$ & $1.3 \ldots 1.5$ \\
\hline & $\begin{array}{l}\text { (Deutscher Ausschuss für Stahlbe- } \\
\text { ton Entwurf, März 2011; Österrei- } \\
\text { chische Bautechnik Vereinigung, } \\
\text { 2018) }\end{array}$ & - & $0.2 \mathrm{~m}$ & $1.5 \ldots 3.0$ & 0.8 \\
\hline & (Jeong, Park, Lim, \& Kim, 2013) $^{(\mathrm{b})}$ & - & $0.2 \mathrm{~m}$ & 2.88 & 2.00 \\
\hline & (Jeong et al., 2013) ${ }^{(b)}$ & polyethylen sheet & $0.2 \mathrm{~m}$ & 0.65 & 0.33 \\
\hline & (Pettersson \& Alemo, 2000) & $\begin{array}{l}\text { plastic sheets } \\
(0.15 \mathrm{~mm})\end{array}$ & $0.2 \mathrm{~m}$ & 1.0 & \\
\hline \multirow[t]{2}{*}{$\begin{array}{l}\text { gravel }- \text { sand - } \\
\text { soil replacement }\end{array}$} & $\begin{array}{l}\text { (Deutscher Ausschuss für } \\
\text { Stahlbeton, 2006) }\end{array}$ & - & $0.2 \mathrm{~m}$ & $>1.4$ & - \\
\hline & $\begin{array}{l}\text { (Deutscher Ausschuss für } \\
\text { Stahlbeton, 2006) }\end{array}$ & - & $0.8 \mathrm{~m}$ & $\approx 0.9$ & - \\
\hline sand or gravel & (Rubin \& Schneider, 2002) & - & & $0.35-0.6$ & - \\
\hline $\begin{array}{l}\text { sand layer } \\
\text { (thickness } 6 \text { to } \\
10 \mathrm{~cm} \text {, average } \\
\text { grain size } \\
0,35 \mathrm{~mm} \text { ) }\end{array}$ & $\begin{array}{l}\text { (Deutscher Ausschuss für } \\
\text { Stahlbeton, 2006) }\end{array}$ & $\begin{array}{l}\text { none (direct on } \\
\text { non-fine-grained, } \\
\text { cohesive soil) }\end{array}$ & & 0.7 & - \\
\hline \multirow[t]{6}{*}{$\begin{array}{l}\text { sandy soil or } \\
\text { coarse soil with } \\
\text { sand bedding } \\
\text { under the slab }\end{array}$} & $\begin{array}{l}\text { (Deutscher Ausschuss für Stahlbe- } \\
\text { ton Entwurf März 2011; Österrei- } \\
\text { chische Bautechnik Vereinigung, } \\
\text { 2018) }\end{array}$ & - & & $0.9 \ldots 1.1$ & $0.6 \ldots 0.8$ \\
\hline & (Pettersson \& Alemo, 2000) & - & $0.2 \mathrm{~m}$ & 1.2 & $0.7 \ldots 0.8$ \\
\hline & (Pettersson \& Alemo, 2000) & $\begin{array}{l}\text { plastic sheets } \\
(0.15 \mathrm{~mm})\end{array}$ & $0.2 \mathrm{~m}$ & 0.9 & $0.5 \ldots 0.6$ \\
\hline & (Lohmeyer \& Ebeling, 2013) & $\begin{array}{l}\text { nimpled sheet } \\
(\mathrm{d} \approx 0.6 \mathrm{~mm})\end{array}$ & & $0.8 \ldots 1.0$ & - \\
\hline & $\begin{array}{l}\text { (Österreichische Bautechnik Ver- } \\
\text { einigung, 2018) }\end{array}$ & 1 layer of PE-foil & & $0.5 \ldots 0.7$ & - \\
\hline & Authors & 2 layers of PE-foil & $0.18 \mathrm{~m}$ & $\approx 0.75-0.9$ & $\approx 0.7-0.8$ \\
\hline \multirow{9}{*}{$\begin{array}{l}\text { levelling con- } \\
\text { crete, trowelled } \\
\text { up (macro } \\
\text { rough) }{ }^{c)}\end{array}$} & \multirow{3}{*}{$\begin{array}{l}\text { (Deutscher Ausschuss für } \\
\text { Stahlbeton, 2006) }\end{array}$} & $\begin{array}{l}\text { thick foil with sili- } \\
\text { con grease }\end{array}$ & & $\approx 0.8$ & - \\
\hline & & \multirow{2}{*}{2 layers of PE-foil } & $0.3 \mathrm{~m}$ & $\approx 2.0$ & - \\
\hline & & & $1.5 \mathrm{~m}$ & $\approx 1.3$ & - \\
\hline & \multirow{2}{*}{$\begin{array}{l}\text { (Deutscher Ausschuss für Stahlbe- } \\
\text { ton Entwurf, März 2011; } \\
\text { Lohmeyer and Ebeling 2012) }\end{array}$} & asphalt sheeting d) & \multirow{2}{*}{$\begin{array}{l}\text { not rele- } \\
\text { vant }\end{array}$} & $0.35-0.7$ & - \\
\hline & & bitumen ${ }^{\mathrm{d})}$ & & $0.03-0.2$ & - \\
\hline & (Jeong et al., 2013) $^{(b)}$ & - & $0.2 \mathrm{~m}$ & 0.77 & 0.77 \\
\hline & \multirow{3}{*}{ (Lohmeyer \& Ebeling, 2018) } & \multirow{2}{*}{$\begin{array}{l}\text { foil under levelling } \\
\text { layer (moist sand) }\end{array}$} & $<0.3 \mathrm{~m}$ & $\approx 0.8-1.0$ & - \\
\hline & & & $\geq 0.8 \mathrm{~m}$ & $\approx 0.5-0.7$ & - \\
\hline & & foil + isolation & $<0.3 \mathrm{~m}$ & $\approx 0.8$ & - \\
\hline
\end{tabular}


End of Table 1

\begin{tabular}{|c|c|c|c|c|c|}
\hline Subbase $^{\text {a) }}$ & Reference & $\begin{array}{l}\text { Separation / slid- } \\
\text { ing layer }\end{array}$ & $\begin{array}{c}\text { Slab } \\
\text { thickness }\end{array}$ & $\begin{array}{c}\text { Friction } \\
\text { coefficient } \mu_{\text {eff }} \\
\text { for first } \\
\text { displacement }\end{array}$ & $\begin{array}{c}\text { Friction } \\
\text { coefficient } \mu_{\mathrm{r}} \text { for } \\
\text { repeated } \\
\text { displacement }\end{array}$ \\
\hline \multirow{9}{*}{$\begin{array}{l}\text { Levelling con- } \\
\text { crete, power } \\
\text { trowelled }\end{array}$} & $\begin{array}{l}\text { (Österreichische Bautechnik Ver- } \\
\text { einigung, 2018) }\end{array}$ & 1 layer of PE-foil & \multirow{6}{*}{$0.2 \mathrm{~m}$} & $0.8-1.4$ & - \\
\hline & $\begin{array}{l}\text { (Deutscher Ausschuss für Stahlbe- } \\
\text { ton Entwurf, März 2011; Leon- } \\
\text { hardt, Schade, \& Sommer, 1996); } \\
\text { Öserreichische Bautechnik Verei- } \\
\text { nigung, 2018) }\end{array}$ & $\begin{array}{l}2 \text { layers of PE-foil, } \\
\text { slightly soiled }\end{array}$ & & $0.6-1.0$ & $0.3-0.75$ \\
\hline & (Leonhardt et al., 1996) & $\begin{array}{l}2 \text { layers of PE-foil, } \\
\text { ideal clean }\end{array}$ & & $0.4-0.5$ & - \\
\hline & (Leonhardt et al., 1996) & $\begin{array}{l}2 \text { layers of sliding } \\
\text { foil with lubricants }\end{array}$ & & $\approx 0.3$ & - \\
\hline & $\begin{array}{l}\text { (Deutscher Ausschuss für } \\
\text { Stahlbeton 2006) }\end{array}$ & $\begin{array}{l}\text { thick foil with sili- } \\
\text { con grease as lub- } \\
\text { ricant }\end{array}$ & & $0.28-0.33$ & - \\
\hline & $\begin{array}{l}\text { (Deutscher Ausschuss für Stahlbe- } \\
\text { ton Entwurf, März 2011) }\end{array}$ & PTFE-foil & & $0.2-0.5$ & $0.2-0.3$ \\
\hline & $\begin{array}{l}\text { (Deutscher Ausschuss für } \\
\text { Stahlbeton, 2006) }\end{array}$ & \multirow{2}{*}{$\begin{array}{l}\text { 1- to 2-layered as- } \\
\text { phaltsheeting } \\
(\mathrm{d}>5 \mathrm{~mm})\end{array}$} & $0.3 \mathrm{~m}$ & $\approx 0.45$ & - \\
\hline & $\begin{array}{l}\text { (Deutscher Ausschuss für } \\
\text { Stahlbeton, 2006) }\end{array}$ & & $1.0 \mathrm{~m}$ & $\approx 0.2$ & - \\
\hline & (Spindler, 2015) & coated foil & & $0.1-0.15$ & - \\
\hline \multicolumn{6}{|c|}{$\begin{array}{l}\text { a) levellness: } \pm 2 \mathrm{~cm} \text {, measured in pattern of } 5 \times 5 \mathrm{~m} \text {, average has to be specified height (Deutscher Beton- und Bautechnik-Ver- } \\
\text { ein e.V., 2017), requires enhanced demand on the surface of the subbase regarding levelness and flatness according to DIN } \\
\text { 18202, Table 3, row } 1 \text { (DIN } 1820204-2013 \text { ) }\end{array}$} \\
\hline \multicolumn{6}{|c|}{ b) calculated from researchers results assuming concrete density of $2.4 \mathrm{kN} / \mathrm{dm}^{3}$} \\
\hline \multicolumn{6}{|c|}{$\begin{array}{l}\text { c) effectiveness of asphalt sheets or bitumen layser is only ensured with sufficient thickness and temperatures }>10^{\circ} \mathrm{C} \text {. values are } \\
\text { empirical (Lohmeyer \& Ebeling, 2012) } \\
\text { according to ((Deutscher Ausschuss für Stahlbeton Entwurf, März 2011) } \mu=0 \text {, if the temperature } \mathrm{T}>0{ }^{\circ} \mathrm{C} \text { is ensured in the } \\
\text { sliding layer (usually below the concrete slab) }\end{array}$} \\
\hline \multicolumn{6}{|c|}{ d) closed surface, free of burrs and grooves; levelness according to DIN 18202 , Table 3 , row $2 \mathrm{a}$} \\
\hline
\end{tabular}

As conclusion, the effectiveness of simply placed double-layered PE-foils is relatively low. The friction coefficient ranges between $0.6-1.0$ in case of a power trowelled levelling concrete layer and up to 2.0 in case of a trowelled, macro rough surface. Hence, the achievable friction coefficients strongly depend on the roughness of the subbase. The friction coefficient of a slab resting on normal sand ranges between $0.9-1.1$, in case of fine sand $(<0.35 \mathrm{~mm})$ even at 0.7. According to the ÖVBB-Guideline (Österreichische Bautechnik Vereinigung) even with one layer of PE-foil a friction coefficient of $0.5-0.7$ was achievable. It is evident, that an additional sliding layer of sand is more effective in reducing friction than multi-layered PE-foils. If the levelling layer has also a sliding function (i.e. sand), the use of one layer PE-foil just as a separation layer between concrete slab and levelling layer is sufficient.

If there is a demand on enhanced stiffness of the subbase, a sliding layer on a power trowelled levelling concrete is an effective way of reducing friction. In this case, the minimum requirements are two layers of PE-foil, because they now act as separation and sliding layer in one. If the levelling concrete is not power trowelled, more effective friction reducing materials, like silicon greased foils or asphalt sheeting shall be used.

Bituminous sliding layers show visco-elastic behaviour. With increasing vertical pressure the shear stress increase in the interface is equivalent, which results in a constant friction coefficient, independent on vertical stresses (Röhling, 2009). The calculation of friction coefficients for bituminous layers is complicated due to dependencies of temperature, stress duration and especially the deformation rate (Curbach \& Bösche, 1998). Slow deformations $(0.02$ to $0.1 \mathrm{~mm} / \mathrm{h}$ ) at temperatures between 10 and $15{ }^{\circ} \mathrm{C}$ are absorbed nearly stress free (Röhling, 2009).

In case of industrial floors, it is practical to pour the concrete directly from the mixing truck onto the surface. In this case, a sliding layer of sand is not adequate. The sliding layer is then placed directly on the subbase (in most cases frost protection gravel). Unfortunately, for this case there are very less experimental values for the friction coefficient available. According to Table 1 the friction coefficient should range between 0.8 (two layers of PE-foil on sand) and 1.4 (coarse subbase without sliding layer). Further investigations are required. 


\section{Own experimental investigations}

\section{Test equipment and performance}

The test program includes three specimens with dimensions of $1.0 \times 1.0 \times 0.18 \mathrm{~m}$, consisting of macro glass fibre reinforced concrete with a compressive strength class of C30/37. Mix proportions of the concrete are reported in (Löber, Heiden, \& Holschemacher, 2017). The specimens were cast in wooden moulds directly resting on the prepared subbase. They were demoulded after one day and tested directly on the site after 108 days, because concrete strength was not relevant for this test. In each specimen, a threaded sleeve was placed in the gravity axis during concreting. At the testing day, a threaded rod was screwed in the sleeve to secure load transmission. The threaded rod was linked with a joint connected to the $5 \mathrm{kN}$ load cell and another threaded rod which was connected with the hydraulic jack. The hydraulic jack was placed horizontally on a double c steel profile, which was anchored with an excavator. The displacement of the specimens was measured in horizontal direction along the gravity axis on the other side with a $20 \mathrm{~mm}$ LVDT. The test was conducted via displacement control whereas the stroke was induced and regulated manually. The average loading rate was at $0.01 \mathrm{~mm} / \mathrm{s}$ until $10 \mathrm{~mm}$ displacement. Afterwards the loading rate was increased. Details of the test setup are shown in Figure 3.

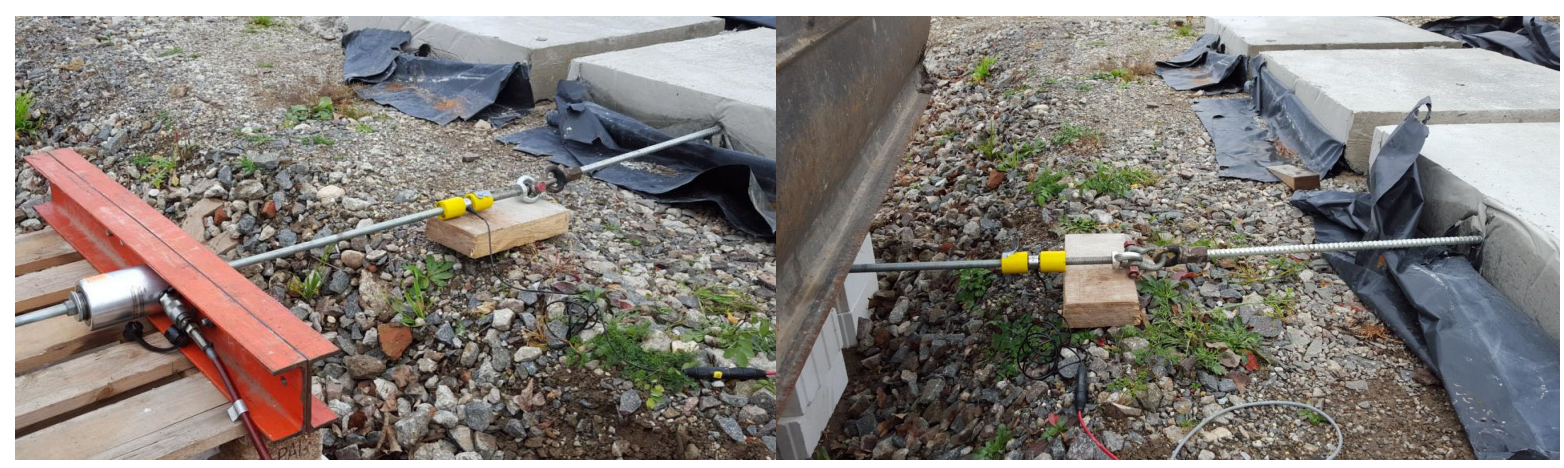

Figure 3. Test setup on site

\section{Preparation of subbase}

Before casting, the subbase was prepared according to Figure 4, consisting of a $30 \mathrm{~cm}$ layer of crushed gravel (not classified) on the subgrade. The gravel was compacted with a vibrator and covered with a $5 \mathrm{~cm}$ layer of sand $(0 / 2 \mathrm{~mm})$ and two layers of PE-foil, which should function as separation and sliding interface.

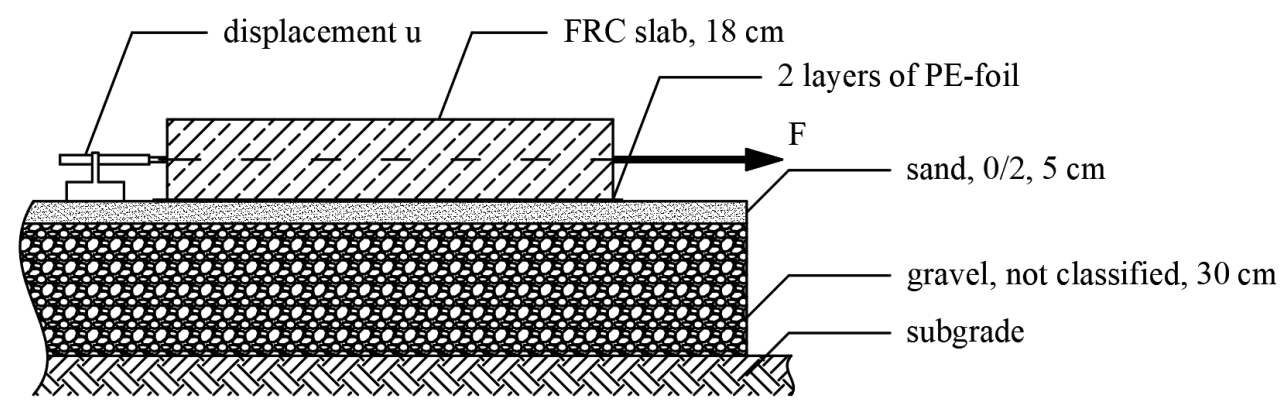

Figure 4. Sketch of the test setup

\section{Test results}

Figure 5 shows the friction curves for all three specimens, whereas the measured force $F_{\mathrm{r}}$ is calculated into friction coefficient $\mu$ according to Eq. (4) and is plotted versus horizontal displacement $u$. 


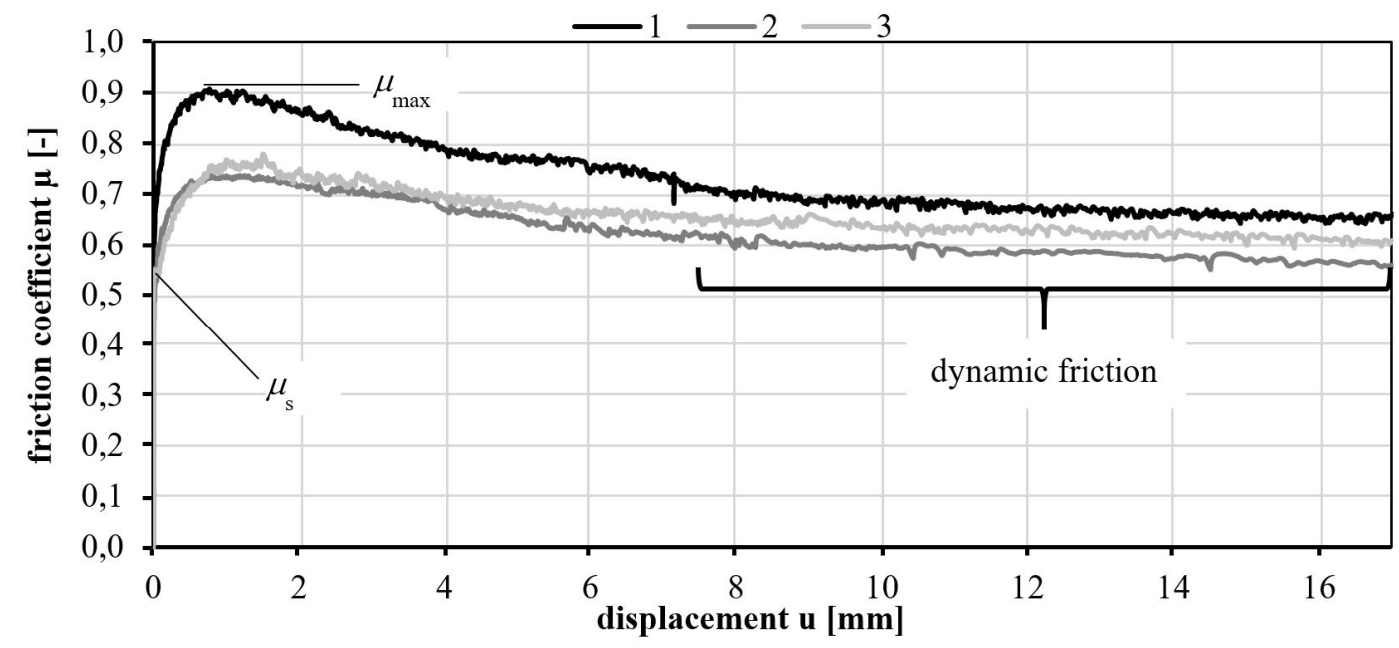

Figure 5. Friction curves of the investigated specimens

The results show a local maximum, which represents the effective friction coefficient $\mu_{\max }$. With increasing displacement of the specimen, the load becomes constant, which equals the friction coefficient for sliding $\mu_{\text {dyn. }}$ Up to a displacement of approximately $0.1 \mathrm{~mm}$ the system of slab-sliding interface is in a mobilization range, where bond stresses build up to the static friction $\mu_{\mathrm{s}}$ (Deutscher Ausschuss für Stahlbeton, 2006).

The normal force in the joint $F_{\mathrm{N}}$ was calculated using the individual geometry of each specimen and the average density of all tested concrete specimens.

Table 2. Summary of results

\begin{tabular}{|c|c|c|c|c|c|c|c|c|c|}
\hline 11 & $\varnothing$ a & $\varnothing \mathrm{b}$ & $\varnothing \mathrm{d}$ & $\varnothing \rho$ & $F_{\mathrm{N}}$ & $F_{\max }$ & $F_{\text {dyn }}$ & $\mu_{\max }$ & $\mu_{\mathrm{dyn}}$ \\
\hline Siau & {$[\mathrm{mm}]$} & {$[\mathrm{mm}]$} & {$[\mathrm{mm}]$} & {$\left[\mathrm{kg} / \mathrm{dm}^{3}\right]$} & {$[\mathrm{kN}]$} & {$[\mathrm{kN}]$} & {$[\mathrm{kN}]$} & {$[-]$} & {$[-]$} \\
\hline 1 & 1001.5 & 1001.0 & 183.5 & \multirow{4}{*}{2.280} & 4.19 & 3.804 & 2.666 & 0.907 & 0.701 \\
\hline 2 & 996.5 & 1003.5 & 179.3 & & 4.09 & 3.012 & 2.074 & 0.737 & 0.688 \\
\hline 3 & 1002.0 & 1001.0 & 183.8 & & 4.20 & 3.271 & 2.491 & 0.778 & 0.762 \\
\hline$\varnothing$ & 1000.0 & 1001.8 & 182.2 & & 4.16 & 3.362 & 2.410 & 0.807 & 0.717 \\
\hline
\end{tabular}

The results are showing a scatter between $\mu_{\max }=0.73$ to 0.91 and therefore an empirical coefficient of variation of $12 \%$. The average value of $\mu_{\max }=0.81$ can be classified in accordance to the results from other researchers (see Table 1).

\section{Conclusions}

With the demonstrated test setup, it was possible to receive static and dynamic friction coefficients of slabs resting on two-layered PE-foil over a $5 \mathrm{~cm}$ layer of sand on gravel. The results are align with others found in literature and complement the investigations by this additional case. In general, very low values for the effective friction coefficient are possible, if subgrade, levelling and sliding layer are produced carefully. In practice a lot of factors influencing the friction negatively take effect like dirt, roughness of the interface or levelness. It has to be mentioned that an even underground is very important to reduce restraint stresses resulting from differences in slab stiffness, which would lead to higher stress peaks and reduced sliding potential of the slab.

\section{Acknowledgements}

The authors would like to thank all contributors, especially the contracting company Otto Heil GmbH \& Co. KG for preparation of the test site, casting and support during the tests.

\section{References}

Curbach, M., \& Bösche, T. (1998). Verwendung von Bitumen als Gleitschicht im Massivbau. DAfStb Heft 485. Beuth, Berlin. Deutscher Ausschuss für Stahlbeton. (2006). DAfStb-Erläuterungen zur Richtlinie Wasserundurchlässige Bauteile aus Beton (WURichtlinie), DAfStb Heft 555. Beuth, Berlin. 
Deutscher Ausschuss für Stahlbeton. (2017). DAfStb-Richtlinie Wasserundurchlässige Bauwerke aus Beton (WU-Richtlinie).

Deutscher Ausschuss für Stahlbeton. (Entwurf 2011). DAfStb-Richtlinie Betonbau beim Umgang mit wassergefährdenden Stoffen (BUmwS).

Deutscher Beton- und Bautechnik-Verein e.V. (2017). DBV-Merkblatt Industrieböden aus Beton.

Jeong, J.-H., Park, J.-Y., Lim, J.-S., \& Kim, S.-H. (2013). Testing and modelling of friction characteristics between concrete slab and subbase layers. Road Materials and Pavement Design, 15(1), 114-130. https://doi.org/10.1080/14680629.2013.863161

Leonhardt, B., Schade, G., \& Sommer, R. (1996). Wasserundurchlässige Becken und Behälter in Stahlbeton. Beton-Informationen, 36(3), 34-47.

Löber, P., Heiden, B., \& Holschemacher, K. (2017). Creep behaviour of macro glass fibre reinforced concrete beams. IOP Conference Series: Materials Science and Engineering, 246(1), 012028. https://doi.org/10.1088/1757-899X/246/1/012028

Lohmeyer, G., \& Ebeling, K. (2012). Betonböden für Produktions- und Lagerhallen: Planung, Bemessung, Ausführung. Bau + Technik, Erkrath.

Lohmeyer, G., \& Ebeling, K. (2013). Weiße Wannen - einfach und sicher: Konstruktion und Ausführung wasserundurchlässiger Bauwerke aus Beton. Verl. Bau + Technik, Düsseldorf.

Lohmeyer, G., \& Ebeling, K. (2018). Weiße Wannen - einfach und sicher: Planung und Konstruktion wasserundurchlässiger Bauwerke aus Beton. Verlag Bau + Technik, Erkrath.

Normenausschuss Bauwesen (NABau) im DIN. (2013). Toleranzen im Hochbau - Bauwerke (DIN 18202). Berlin.

Österreichische Bautechnik Vereinigung (ÖBV). (2018). ÖVBB-Richtlinie: Wasserundurchlässige Betonbauwerke - Weiße Wannen. Österreichischer Betonverein. Wien.

Pettersson, D., \& Alemo, J. (2000). Characterization of restraint from friction tests with slabs cast on ground. Structural Concrete, 1(4), 181-187. https://doi.org/10.1680/stco.2000.1.4.181

Röhling, S. (2009). Zwangsspannungen infolge Hydratationswärme. Verlag Bau + Technik, Düsseldorf.

Rubin, H., \& Schneider, K.-J. (2002). Baustatik - Theorie I. und II. Ordnung. Werner.

Schütte, J. (1997). Einfluß der Lagerungsbedingungen auf Zwang in Betonbodenplatten (Dissertation). Institut für Baustoffe, Massivbau und Brandschutz (iBMB) der TU Braunschweig, Materialprüfanstalt (MPA) für das Bauwesen Braunschweig.

Spindler, M. (2015). Bemessung von Industriefußböden. Retrieved from http://www.hit-industrieboden.de/planungbemessung.html 